\title{
A review on the plant secondary metabolites with special context with North East India
}

\author{
Devi Ritismita, Manash Pratim Sarma \\ Department of Biochemistry, Assam Down Town University, Assam, India
}

\begin{tabular}{l}
\hline \hline Article Info \\
\hline Article history: \\
Received Jun 25, 2020 \\
Revised Oct 21, 2020 \\
Accepted Feb 3, 2021 \\
\hline
\end{tabular}

\section{Keywords:}

Ayurveda treatment

Cardiac disease

Extracting phytochemicals

Homeostasis

Metabolites

Phytocompounds

\begin{abstract}
Extracting phytochemicals or phytocompounds for the upliftment of general health and sustainability is one of the greatest needs of the millennium. Plants have immense quality in regard to secondary metabolites although not required for general growth and development yet are very much necessary for forming a protective gear and maintaining homeostasis. With their immense diversity in curing various diseases, these plants' secondary metabolites therefore must be put forth and given much importance in generation and production from the root level to the mission worldwide. Along with the increasing cases of failure in the usage of chemotherapeutic drugs and their utilities, the implementation of secondary metabolites for their various medicinal characteristic in therapeutic cases are also increasing in demand. With the increasing demand for Ayurveda treatment and the popularity of the mass, it can be positively taken up as a means of earning capital and making self-sustaining. NorthEastern states of India in this regard are a vital source of income and also a media to generate and bring indigenous products to the world.
\end{abstract}

This is an open access article under the CC BY-SA license.

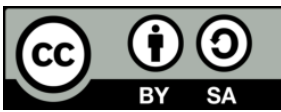

\section{Corresponding Author:}

Manash Pratim Sarma

Department of Biotechnology

Assam down town University

Sankar Madhab Path Gandhi Nagar, Panikhaiti, Guwahati, Assam 781026, India

Email: manash3268@gmail.com

\section{INTRODUCTION}

Plants the most successful form of life on earth, have evolved numerous characteristics to overcome the challenge of immobility, through physical and biochemical pathways, enabling the mechanisms of their self/cross-pollination and dispersal of seeds, fighting variations in climatic changes and the coexistence with herbivores and pathogens which are the intruders [1], [2]. Plants produce a vast and varied combination of organic compounds, amongst which most do not appear to have a direct relationship in growth and development. These secondary metabolites, very often are diversely spread amongst restricted taxonomic groups within the plant kingdom. Various biochemical pathways permitted the synthesis of phytochemicals. Secondary metabolites created from primary ones do not have direct involvement in the growth, development, and reproduction but are molecules that primarily involve in the overall maintenance, a state called homeostasis of the organism [1]. Secondary metabolites are generally not required in standard metabolic processes but are important for protection, protection, competition, and species interactions, but are not necessary for survival. Secondary metabolites are specific in maintaining several health processes, such as sustaining the healthy functional status of the cells within organ systems of the organism [3]. These are also referred to an as rich reservoirs of bioactive compounds. In comparison with primary metabolites, secondary metabolites present in plants are an integral part of the communication of plants with their environment. These have diverse chemical 
structures and biological activities. These are the major mechanism against herbivores, pest, and pathogens [2]-[4].

Secondary metabolites are expressed in numerous combinations all through the plant starting from the leaves, roots, shoots, bark, at different stages of growth such as seedling till the mature tree as shown in Table 1. Once thought to be worthless waste material, secondary metabolites are now considered to be invaluable constituents of plants being expressed to gain a selective, adaptive advantage by these sessile organisms. Although it is so very important yet only a small percentage of it has been phytochemicals investigated [5]. Anti-oxidants like phenols, steroids, and flavonoids make them beneficial food items besides being rich in vitamins, minerals (10 types), and amino acids (17 types). Besides their nutritional aspect, they are believed to have anti-aging properties, decrease blood cholesterol, acts as appetizers, enhanced appetite, and are believed to have anti-microbial properties [6].

\section{PHYTOCHEMICALS}

Phytochemicals are not vitamins or minerals but are a bioactive compound found in plant foods that work with nutrient and dietary fibers to protect against disease [7]. Phytochemicals naturally occur in plants providing them color, odor, and flavor. They also influence the various chemical processes inside our bodies in useful ways. Thousands of phytochemicals have been identified for which scientists have only begun to investigate their potentiality [8]-[11]. Lists some of the phytochemicals with their food sources and potential benefits.

Table 1. List of phytochemicals with their sources and benefits

\begin{tabular}{|c|c|c|}
\hline Phytochemicals & Their Source & Their Benefits \\
\hline Carotenoids & $\begin{array}{l}\text { Red, green, yellow, orange fruits and vegetables } \\
\text { especially carrots, sweet potatoes, winter squash, } \\
\text { tomatoes, citrus, melons, cruciferous vegetables. }\end{array}$ & $\begin{array}{l}\text { Antioxidants; reduce the accumulation of plaque in } \\
\text { arteries, promote cell differentiation. }\end{array}$ \\
\hline Flavonoids & $\begin{array}{l}\text { Most fruits and vegetables, especially citrus, } \\
\text { onions, apples, grapes, tea. }\end{array}$ & $\begin{array}{l}\text { Antioxidants for carcinogens suppress malignant } \\
\text { changes. Protect eyes, nerves from inflammation and } \\
\text { damage from diabetes: improve symptoms of allergy, } \\
\text { asthma, and arthritis. }\end{array}$ \\
\hline Ellagic Acid & Strawberries, grapes, raspberries, apples & $\begin{array}{l}\text { Neutralize cancer-causing chemicals found in tobacco } \\
\text { smoke, processed foods, and barbecued meats. }\end{array}$ \\
\hline Phenolic Acids & $\begin{array}{l}\text { Citrus, whole grains, berries, tomatoes, peppers, } \\
\text { parsley, carrots, cruciferous vegetables, squash, } \\
\text { yams, most other fruits, and vegetables. }\end{array}$ & $\begin{array}{l}\text { Help resist cancer by inhibiting cell proliferation induced } \\
\text { by carcinogens in target organs, inhibit platelet activity, } \\
\text { decrease inflammation, and act as antioxidants. }\end{array}$ \\
\hline Indoles & $\begin{array}{l}\text { Cruciferous vegetables, such as broccoli, cabbage, } \\
\text { kale }\end{array}$ & $\begin{array}{l}\text { Block cancer-causing substances before they can damage } \\
\text { cells. }\end{array}$ \\
\hline $\begin{array}{l}\text { Isothiocyanates, } \\
\text { such as } \\
\text { sulforaphane }\end{array}$ & Cruciferous vegetables & Inducing protective enzymes; suppressing tumor growth. \\
\hline Lignans & Flax seeds, berries, whole grains & $\begin{array}{l}\text { Antioxidants and insoluble fibers, block or suppress } \\
\text { cancerous changes; particularly protective against colon } \\
\text { cancer and heart disease. }\end{array}$ \\
\hline Saponins & Garlic, onions, legumes, soybeans, & $\begin{array}{l}\text { Inhibit tumor promoters induced by excessively fatty } \\
\text { diet: lower circulating levels of fats. }\end{array}$ \\
\hline $\begin{array}{l}\text { Protease } \\
\text { Inhibitors }\end{array}$ & All, plants, especially soybeans & $\begin{array}{l}\text { Reduce inflammation of arthritis; antiviral and } \\
\text { antibacterial; suppress the enzyme }\end{array}$ \\
\hline
\end{tabular}

\section{INDIAN DISCOVERIES WITH PHYTOCHEMICAL DATABASES}

Plant components found naturally are predominantly found to treat various ailments. These secondary metabolites exert various significant pharmacological and toxic effects on human beings. These chemically active compounds are the metabolites found primarily and secondarily depending on the chemical structure, functional groups, and derivatives [12]. Medicinal plants which have an important role in averting diseases like diabetes, cancer, disease related to the heart have plentiful bioactive. The major classes of phytochemicals with disease-preventing functions are dietary fibers, antioxidants, anticancer, detoxifying agents, immunity-potentiating agents, and neuropharmacological agents as shown in Figure 1. Each class of these functional agents consists of a wide range of chemicals with differing potency [4]. Phytochemical analysis of the extract indicated the presence of saponin, phenol, phytosterol, steroid, terpenoid, flavonoid, carbohydrates, and proteins while tannin, glycoside and plobatanin were absent [13]. India is rich in the flora of indigenous medicinal plants has been used for centuries in traditional Indian medicine to treat human diseases. Phytochemicals of medicinal plants include a diverse chemical space for drug discovery. IMPPAT, a comprehensive online database on the phytochemistry of Indian medicinal plants enables 
computational approaches towards natural product-based drug discovery. It is a manually curated database of 1742 Indian Medicinal Plants, 9596 Phytochemicals, and 1124 Therapeutic uses spanning 27074 plantphytochemical associations and 11514 plant-therapeutic associations. Within IMPPAT, about a subset of 960 potential drug gable phytochemicals is filtered, of which majority have no significant similarity to existing FDA-approved drugs, and thus, rendering them as good candidates for prospective drugs [4].

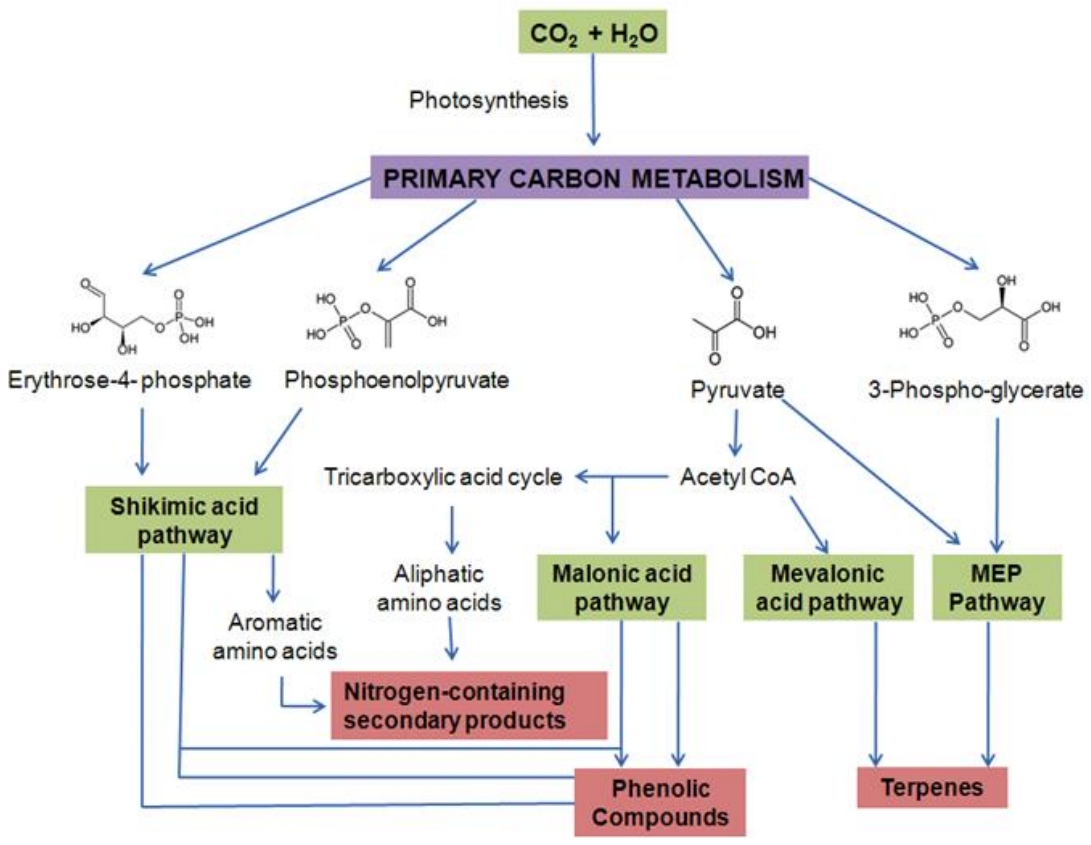

Figure 1. The production of secondary metabolites is tightly associated with the pathways of primary/central metabolism

\section{AVAILABILITY IN NORTHEASTERN INDIA}

According to Kumar et al. [14], Vaidya and Devasagayam. [15], Narayana stated that:

"States of the North East in the country are best suited for medicinal plant supply chain with their topography, soil and climatic conditions,"

North East India comprises seven states i.e., Arunachal Pradesh, Assam, Manipur, Meghalaya, Mizoram, Nagaland, Sikkim, and Tripura distinguished by diverse physical geography, starting from plains, plateaus, and mountains with associated valleys. The region receives moderately high rainfall. About 200 tribes of different ethnic groups with distinct cultural entities inhabit the region where agriculture is the main occupation of the people and the crops grown are rice, brinjal, ginger, chilies, maize, turmeric, potato, cucurbits, taros, and yams [16], [17]. The inhabitants of the hilly regions practice 'Jhum' or 'Shifting' cultivation in which they cultivate cereals, vegetables, and fruits. A rich variety of germplasm exists under various crops that include upland rice, brinjal, ginger, chilies, maize, turmeric, grain legumes, sweet potato, cucurbits, taros, and yams. The importance of agriculture and the diversity of medicinal plants cannot be ignored when it comes to cultivation in Northeastern India [5], [14], [15], [18].

Since the early 1970's different groups in various Universities and Research Institutions have been working on ethnobotany and traditional knowledge system of the region from where most of the publications were concerned with the agricultural operations or ethical studies in the plant species including shifting cultivation and festivals of the region. Ethnobotanical reports were mainly on age-old locally available medicinal plants with a few information's on food and beverages [19]-[21]. Search for medicinal plants in North Eastern India has been carried out in the various forests including raw and locally prepared drugs markets up to the range wherever medicinal plant products are sold in the markets. Various attempts have also been made for habituation through the cultivation of medicinal plants from one area to another in the region [5], [18].

High-valued medicinal plants from the states of Northeast are tried to cultivate in various environments with changes in habitat. But sustainability rate of such processes is not that much positively

A review on the plant secondary metabolites with special context with North East India (Devi Ritismita) 
counted [22]-[24]. They fail to grow if there's a change in the habitat changed, fail to fruit. Needless to say, fruiting is a major component of pharmaceutics [2].

Based on the observation of the ethnic botanical research publications it may be said that India has a good hold on documentation in this field, however, the country has so far not been able to converge this information into the economic growth and development of itself [18], [25], [26]. The screening of the ethnos medicinal plants for active chemical compounds has to be done to discover new novel drugs. This valuable ethnobotanical information and the enriched region with the resources are on a high alert to be conserved and should be adopted for indigenous utilization by the tribes residing over the region [25]. They should be trained in beneficiary harvest practices and post-harvest techniques for a good yield. The rich bio-resources have to be translated into products and uses without which the rich resources have no value for the poor stricken people of the region who are the custodian of it [27]-[29].

\section{PRESENT SCENARIO ON UTILIZATION OF MEDICINAL PLANTS}

From the ancient periods, medicinal plants are the integral components of traditional medicine systems worldwide. The selection of medicinal plants for therapeutic application by a traditional community is not random but based on certain criteria. These knowledge systems were developed and acquired through many generations [1]-[2]. Cross-cultural knowledge transmissions and acquired knowledge from different media also contribute to enriching this knowledge system. As this system is dynamic, any external influences such as deforestation and socio-cultural changes will hurt such a knowledge system. Northeastern India is immensely rich in medicinal plants and the use of these is being carried over by generations after generations. The traditional attempt of reviving these practices is still on hand but any breakage in the process may lead to loss of data and knowledge [2].

Herbal drugs are essentially important compounds in traditional medicine in several countries including India where Ayurveda, a well-established and highly followed system of medicine using plants, animals, and minerals for the wellbeing of humankind has become a hot spot of mega biodiversity. The government of India has taken several initiatives to develop modern technology which can conserve and further these medicinal plants can be efficient to interrelate research and developmental activities as well as to prepare databases [15]. Priority of the Indian Council of Agricultural Research and the Department of Biotechnology, Government of India demand that the top 20 medicinal plants in India be imported and exported from India according to the world demands [30]-[33]. Pharmacological departments have also validated scientifically the activity of age-old drugs used in Ayurveda has reincarnated faith in the traditional system, of selecting plants only based on experience [1]-[4],[14].

The matter of attraction for the pharmaceuticals, scientists, and traders is the discoveries of the medicinal plants in the states of Northeast India and is being regularly carried out [34]-[37]. Scientific and technological intervention is to be carried out to bring a change in their skills and in converting the rich bioresources into economic wealth. The people should be encouraged to take up entrepreneurship by sustainable utilization of the rich bio-resources and unmatched indigenous knowledge with value-added through scientific and technological incorporations from the various research institutions in the country [38], [39]. The endangered species of indigenous medicinal plants are to be conserved and the knowledge of traditional cultivation should be passed on. These resources can be used to earn capital for the benefit of the people of the region and the country [18], [25], [26].

\section{CONCLUSION}

The secondary metabolites have a great and enormous dynamic impact on humankind and are emerging to be a nature's boon by its rich diversity and variations. The secondary metabolites such as alkaloids, saponin, phenol, phytosterol, steroid, terpenoid, flavonoid, carbohydrates, and proteins while tannin, glycoside and plobatanin have been reported to be potentially active against various ailments. Its importance is increasing due to the failure of several therapeutic chemicals in providing treatment to the conditions prevailing. In the view of providing new and effective treatment therapy, secondary metabolites usage can be a great help to humankind. Also, to add some more goodness to it, the awakening of the rich knowledge of the Indian population on the medicinal plants and their utility will certainly be none other than beneficial for the mass. The growth of entrepreneurship among the local people and the tribes of North-Eastern India will immensely affect its economy as well as will bring focus to the remote areas of India.

\section{ACKNOWLEDGEMENT:}

The authors acknowledge the support from Assam Down Town University. 


\section{REFERENCES}

[1] A. A Mao, TM Hynniewta and M Sanjappa, "Plant wealth of Northeast India with reference to ethnobotany," Indian Journal Of Traditional Knowledge, vol. 8, no. 1, pp. 96-103, 2009,

[2] R. Shankar and M. S. Rawat, "Conservation and cultivation of threatened and high valued medicinal plants in North East India," International Journal of Biodiversity and Conservation, vol. 5, no. 9, pp. 584-591, 2013.

[3] P. K. Hajra, and A. K. Baishya, "Ethnobotanical notes on the Miris (Mishings) of Assam plains," Glimpses of Indian ethnobotany, 161-167, 1981.

[4] R. Majumder, "Some threatened medicinal plants from the Northeast region," Bull. Medico Ethno Bot. Res., vol. 12, no. 1-2, pp. 12-16, 1991.

[5] K. G. Ramawat and S. Goyal, "The Indian Herbal Drugs Scenario in Global Perspectives," Bioactive Molecules and Medicinal Plants, Berlin: Springer, pp. 325-347, 2008.

[6] M. P. Sarma, "Analysis of cyanide concentration in five selected bamboo shoots consumed in North East India," Bioequivalence \& Bioavailability International Journal, vol. 2, pp. 1-4, 2018.

[7] R. Sapam, P. P. Kalita, M. P. Sarma, N. Talukdar, H. Das, "Screening of phytochemicals and determination of total phenolic content, antioxidant and antimicrobial activity of methanolic extract of Piper nigrum leaves," Pharmaceutical Research, vol. 8, no. 02, 2018.

[8] P. Chakraborty, "Herbal genomics as tools for dissecting new metabolic pathways of unexplored medicinal plants and drug discovery," Biochimie open, vol. 6, pp. 9-16, 2018.

[9] P. Palanichamy, G. Krishnamoorthy, S. Kannan and M. Marudhamuthu, "Bioactive potential of secondary metabolites derived from medicinal plant endophytes," Egyptian Journal of Basic and Applied Sciences, vol. 5, no. 4, pp. 303-312, 2018.

[10] S. Takshak, "Bioactive compounds in medicinal plants: A condensed review," SEJ Pharm. Nat. Med, vol. 1, no. 1, pp. 1-35, 2018.

[11] F. R. Patel and N. R. Modi, "Secondary metabolite production from medicinal plants for the treatment of female infertility: A review," Research Journal of Life Sciences, Bioinformatics, Pharmaceutical and Chemical Sciences, 2018.

[12] C. Jain, S. Khatana and R. Vijayvergia , "Bioactivity of secondary metabolites of various plants: a review" International Journal of Pharmaceutical Sciences and Research, vol. 10, no. 2, pp. 494-504, 2019.

[13] M. P. Sarma, "Screening of phytochemicals and evaluation of anti-microbial, anti-oxidant and in-vitro antidiabetic activity of crassula ovata leaves," International Journal of Pharmaceutical Sciences and Research, vol. 8, no. 2, p. 859, 2017.

[14] S. Kumar, P. L. Negi, K. Mikawlrawng, S. Singhal, P. Punia, S. Kumar, P. Sharma, S. Sharma, K. Thakur, S. Kumari, S. Sehgal, A. Dhoundiyal, "Phytochemical screening of important medicinal plants from North-East India," Asian Journal of Biochemical and Pharmaceutical Research, vol. 6, no. 4, 2016.

[15] A. D. B. Vaidya and T. P. A. Devasagayam, "Current status of herbal drugs in India: An overview," Journal of clinical biochemistry and nutrition, vol. 41, no. 1, pp. 1-11, 2007.

[16] B. Das, "New plant species discovered in north-east India," Nature India, 2018. [Online]. Available: https://www.natureasia.com/en/nindia/article/10.1038/nindia.2018.15.

[17] M. Sharma and B. Das, "Medicinal plants of north-east region of India: a small review," International Journal of Current Pharmaceutical Research, vol. 10, no. 4, 2018.

[18] M. A. Salem, L. Perez de Souza, A. Serag, A. R. Fernie, M. A. Farag, S. M. Ezzat and S. Alseekh "Metabolomics in the context of plant natural products research: From sample preparation to metabolite analysis," Metabolites, vol. 10, no. 1 , p. 37,2020

[19] Ravindra H. Patil, Mohini P. Patil, Vijay Laxminarayan Maheshwari, "Bioactive Secondary Metabolites from endophytic Fungi: A review of Biotechnological Production and Their Potential Applications," Studies in Natural Products, vol 49, pp. 189-205, 2016.

[20] S. L. Ndiku, R. K. Nakweti, V. Sinou, F. Rouvier, T. M. Fundu, C. Franche and R. C. Kanianga, "Improvement of secondary metabolites from Phyllanthus odontadenius against malaria by mutagenesis," Journal of Pharmaceutical Research International, vol. 21, no. 2, pp. 1-14, 2018.

[21] T. Isah, "Stress and defense responses in plant secondary metabolites production," Biological research, vol. 52, 2019.

[22] S. Pathak, A. V. Agarwal, P. Agarwa, and P. K. Trivedi "Secondary Metabolite Pathways in Medicinal Plants: Approaches in Reconstruction and Analysis," Molecular Approaches in Plant Biology and Environmental Challenges, pp. 339-364, 2019.

[23] R. Breitling, A. Ceniceros, A. Jankevics, and E. Takano, "Metabolomics for secondary metabolite research," Metabolites, vol. 3, no. 4, pp. 1076-1083, 2013.

[24] B. O. Oyeyinka and A. J. Afolayan, "Comparative and correlational evaluation of the phytochemical constituents and antioxidant activity of musa sinensis L. and musa paradisiaca L. fruit compartments," The Scientific World Journal, 2020.

[25] A. Razzaq, B. Sadia, A. Raza, M. K. Hameed and F. Saleem, "Metabolomics: A Way Forward for Crop Improvement," Metabolites, vol. 9, no. 12, p. 303, 2019

[26] U. Anand, N. Jacobo-Herrera, A. Altemimi and N. Lakhssassi, "A comprehensive review on medicinal plants as antimicrobial therapeutics: Potential avenues of biocompatible drug discovery," Metabolites, vol. 9, no. 11, p. 258, 2019.

[27] Wink M. 1999, "Biochemistry of plant secondary metabolism. Annual plant reviews", Volume 2. 374 pp. Sheffeld: Sheffeld Academic Press Ltd. 
[28] R. A. Hussain and A. A. El-Anssary, "Plants secondary metabolites: The key drivers of the pharmacological actions of medicinal plants," Herbal Medicine, vol. 1, p. 13, 2019.

[29] M. Zaynab, M. Fatima, Y. Sharif, M. H. Zafar, H. Ali and K. A. Khan, "Role of primary metabolites in plant defense against pathogens," Microbial pathogenesis, vol. 137, 2019.

[30] M. Alberto, A. Alde, E. Amores, M. De guzman, R. Diolola, R. Garcia, R. Lagaras, C. Tugna, and F. Andal, "Comparison of phytochemical composition of $\mathrm{m}$. Oleifera leaves in selected lowland and highland regions of cavite," Phytochemical Analysis of M. Oleifera, 2019.

[31] K. Chokhone, N. Talukdar, M. P. Sarma, K. Das and P. P. Kalita, "Screening of phytochemicals and evaluation of anti- microbial, anti-oxidant and in vitro antidiabatic activity of Crassula Ovata Leaves," International Journal of Pharmaceutical Sciences and Research, vol. 8, no. 2, p. 859, 2017.

[32] B. Minakshi, D. Jharna, E. Chanbi Devi, T. Nayan, P. K. Partha, N. Kundal, and P. S. Manash, "Phytochemical analysis of traditional medicinal plants and their antimicrobial activity: An experience from North East India," Open Access Journal of Pharmaceutical Research, vol. 1, pp. 1-7, 2016.

[33] M. P. Sarma, F. Munim, M. Bhattacharjee, "Medicinal Plants from North east India:Does the answer lies within", Bioequivalence \& Bioavailability International Journal vol. 1, no. 2, 2017.

[34] R. Sapam, P. P. Kalita, M. P. Sarma, N. Talukdar, and H. Das, "Screening of Phytochemicals and Determination of Total Phenolic Content, Anti-Oxidant and Antimicrobial Activity of Methanolic Extract of Piper Nigrum Leaves," Pharmaceutical Research, vol. 8, no. 02, 2018.

[35] R. Tiwari and C. S. Rana, "Plant secondary metabolites: A review," International Journal of Engineering Research and General Science, vol. 3, no. 5, pp. 661-670, 2015.

[36] T. Olivoto, M. Nardino, I. R. Carvalho, D. N. Follmann, V. J. Szareski, M. Ferrari, A. J. de Pelegrin and V. Q. de Souza "Plant secondary metabolites and its dynamical systems of induction in response to environmental factors: A review," African Journal of Agricultural Research, vol. 12, no. 2, pp. 71-84, 2017.

[37] A. Kar, "Making medicinal plant wealth work for Northeast India," Teriin, 2019. [Online]. Available: https://www.teriin.org/article/making-medicinal-plant-wealth-work-northeast-india

[38] N. Kikon and T. Angami, "Medicinal and aromatic plants for climate change adaptation: Scope and prospects with special reference to North Eastern Himalayas," Journal of Medicinal Plants, vol. 6, no. 1, pp. 150-155, 2018.

[39] U. Anand, N. Jacobo-Herrera, A. Altemimi, and N. Lakhssassi, "A comprehensive review on medicinal plants as antimicrobial therapeutics: Potential avenues of biocompatible drug discovery," Metabolites, vol. 9, no. 11, p. 258, 2019 . 